\title{
Could the re-emerging practice of wild boar hunting linked to the recent economic crisis lead to new outbreaks of trichinellosis in Lebanon?
}

Georges Khali1 ${ }^{1,2, *}$ (), Pierre Marty ${ }^{3}$, Karl Hage ${ }^{4}$, Salma Sfeir ${ }^{4}$, Jeanne El Hage ${ }^{5}$, Tarek Bou Assi ${ }^{6}$, Maria Rassam ${ }^{4}$, Christelle Pomares ${ }^{3, *}$, and Elio Mikhael ${ }^{4}$

${ }^{1}$ Medical Microbiology Department, Faculty of Medicine, Saint Joseph University, P.O. Box 11-5076 - Riad El Solh, 11072180 Beirut, Lebanon

${ }^{2}$ Hôpital Saint Joseph des Sœurs de la Croix-Centre Médical Raymond et Aida Najjar, P.O. Box 90-375 Bauchrieh, Dora-Metn, Beirut, Lebanon

${ }^{3}$ Service de Parasitologie-Mycologie, Université Côte d'Azur, Inserm U1065, Centre Hospitalier Universitaire de Nice, 062020 Nice, France

${ }^{4}$ Faculty of Medicine, Saint-Joseph University, P.O. Box 11-5076 - Riad El Solh, 11072180 Beirut, Lebanon

5 Animal Health Laboratory, Lebanese Agricultural Research Institute - LARI, P.O. Box 90-1965, Fanar, El Metn, Lebanon

${ }^{6}$ Department of Laboratory Medicine, Hôpital Saint Joseph des Sœurs de la Croix-Centre Médical Raymond et Aida Najjar, P.O. Box 90-375 Bauchrieh, Dora-Metn, Beirut, Lebanon

Received 16 September 2021, Accepted 10 February 2022, Published online 28 February 2022

\begin{abstract}
Background: Documented trichinellosis outbreaks in Lebanon date back to the late 19th century. The first published outbreaks were attributed to the consumption of wild boar meat, while those that followed incriminated pork. The practice of hunting wild boar is currently re-emerging in Lebanon given the recent economic crisis that has limited the purchase of livestock meat. Results: In Lebanon, at least 15 outbreaks of trichinellosis have been reported since 1870. We report an outbreak in January 2019, where five of the fifteen people present at a barbecue party were diagnosed with trichinellosis after wild boar meat consumption. Two subspecies of wild boar, Sus scrofa libycus and Sus scrofa scrofa, are commonly targeted by hunters. Hunters and consumers are sometimes unaware of the ineffectiveness of freezing meat and cooking over a wood fire to avoid trichinellosis. Unexpectedly, the National Center for Zoonosis Control receives every year 4 samples of wild boar meat, all free of Trichinella sp. larvae. Conclusion: Trichinellosis, a zoonosis typically unrecognized or undeclared, still represents a risk linked to the consumption of meat from wild animals, especially wild boar. Consumers, hunters, veterinarians, and butchers need to be further educated. Government regulation of wild boar hunting should be implemented to prevent further outbreaks.
\end{abstract}

Key words: Trichinellosis, Foodborne, Helminthiasis, Zoonosis, Wild boar.

Résumé - La réémergence de la pratique de la chasse au sanglier liée à la récente crise économique pourraitelle conduire à de nouveaux foyers de trichinellose au Liban ? Contexte : Les épidémies de trichinellose sont documentées au Liban depuis la fin du XIX ${ }^{\text {ème }}$ siècle. Les premiers foyers publiés étaient attribués à la consommation de viande de sanglier, tandis que ceux qui suivirent incriminaient le porc. La pratique de la chasse au sanglier est en train de réapparaître au Liban compte tenu de la récente crise économique qui a limité l'achat de viande de bétail. Résultats : Au Liban, au moins 15 foyers de trichinellose ont été signalés depuis 1870 . Nous rapportons un foyer en janvier 2019, où cinq des quinze personnes présentes à une soirée barbecue ont reçu un diagnostic de trichinellose après consommation de viande de sanglier. Deux sous-espèces de sangliers, Sus scrofa libycus et Sus scrofa scrofa, sont couramment ciblées par les chasseurs. Les chasseurs et les consommateurs ignorent parfois l'inefficacité de la congélation de la viande et de la cuisson au feu de bois pour éviter la trichinellose. De manière inattendue, le Centre National de Contrôle des Zoonoses reçoit chaque année 4 échantillons de viande de sanglier, tous indemnes de larves de Trichinella spp. Conclusion : La trichinellose, zoonose généralement méconnue ou non déclarée, représente toujours un risque lié à la consommation de viande d'animaux sauvages, notamment de sanglier. Les consommateurs, les chasseurs, les vétérinaires et les bouchers doivent être mieux formés. Des réglementations gouvernementales sur la chasse au sanglier devraient être mises en œuvre pour prévenir de nouvelles épidémies.

\footnotetext{
*Corresponding authors: grkhalil@gmail.com; pomares.c@chu-nicer.fr
} 


\section{Introduction}

Trichinellosis has been described many times in Lebanon, ranging from outbreaks to small series in the 20th century $[2,9,11,13-15,17,18,20,24,27,31]$. Outbreaks were also reported in other Mediterranean countries, such as Greece, Italy, and Spain, during the past few years [1, 3, 7, 23, 26, 28].

In recent years, wild boar (Sus scrofa) hunting and wild boar meat consumption was the most described source of outbreaks. Bear and walrus meat consumption was also associated with confirmed trichinellosis in North America, Asia, and Europe [19, 25]. Wild boar meat consumption is associated with Trichinella spiralis infection as well as other species (T. britovi, T. pseudospiralis, and T. papuae) [25]. Undercooked meat and meat-derived products, as well as parasite load are among the most common described risk factors. Clinical signs and symptoms are mainly due to an intestinal phase consisting of diarrhea, abdominal pain, nausea and vomiting, and a larval invasive phase mainly causing fever, facial and/or orbital edema, cutaneous allergy, and myalgia [4]. Trichinellosis is a typical febrile helminthiasis.

During the past two decades, we have observed a drastic decrease in trichinellosis in Lebanon for many reasons, such as the prohibition by the state of an old practice of mixed butcheries (pork vs. other livestock). Moreover, pork meat consumption is limited to some areas in Lebanon as a result of confessional disparity, as well as the small number of pork farms due to more rigid health regulations recently imposed by the state. In contrast, the risk of trichinellosis has been increasing of late because wild boar hunting is becoming more popular in Lebanon. This hunting practice mainly takes place near the southern border of Lebanon, a zone that constitutes a true natural reserve sheltering wild boars, and that is yet to be regulated by the state. Other areas of Lebanon are also involved (Metn, Kesrouan, Chouf, and Bekaa valley). The recent financial crisis in Lebanon has caused basic needs shortages [30]. As a consequence, wild boar hunting has become a source of cheap protein-rich food.

The aim of this paper is to report a recent outbreak of trichinellosis due to wild boar meat consumption in Lebanon, in the context of renewed interest in wild boar hunting due to the recent economic crisis, and integrating it with historical epidemiologic data of trichinellosis in this country.

\section{Materials and methods}

\section{Cases and definition of cases}

Diagnostic criteria for trichinellosis were based on clinical symptoms and biological test results.

A confirmed case of trichinellosis was defined when a patient had consumed infested meat and had clinical signs and symptoms suggestive of trichinellosis, in addition to a positive muscle (deltoid) biopsy [4] or positive serology or seroconversion: considered negative if less than $11 \mathrm{NTU}$, or less than doubling value after 2 weeks [5].

A probable case of trichinellosis was defined when a patient had consumed infested meat followed by signs and symptoms such as intestinal phase symptoms (diarrhea, abdominal pain), as well as larval migration phase symptoms/signs (fever, myalgia, facial or periorbital edema, urticarial rash, and conjunctival or sub-nail hemorrhage). In addition, biological workup of the patient revealing any of the following biologic abnormalities suggestive of the disease resulted in a probable case: eosinophilia $>500$ cells $/ \mu \mathrm{L}$ (norm: $0-450$ cells $/ \mu \mathrm{L}$ ), elevated creatinine phosphokinase (CPK, norm: 10-200 IU/L), or elevated lactate dehydrogenase (LDH, norm: 140-280 IU/L).

Complete blood count (CBC), CPK, and LDH testing was performed on all symptomatic individuals, while serological testing was done only for hospitalized patients.

Serum samples were tested using a commercial qualitative enzyme-linked immuno-sorbent assay (ELISA) for the detection of $\mathrm{IgG}$ class antibodies against Trichinella spp. (NovaTec Immun-diagnostica GmbH, Germany), according to the manufacturer's recommendations. The manufacturer claims that the test has a diagnostic sensitivity and specificity of $100 \%$ and $94.81 \%$, respectively and the testing kit was additionally validated in the laboratory (based on excretory/secretory Trichinella antigens) [5].

The index case allowed us to track and identify all other concomitant and/or consecutive cases by providing a list of people who consumed the wild boar meat.

\section{Literature review and inquiry with Lebanese wild boar hunters and the head of the Animal Health Laboratory, Lebanese Agricultural Research Institute (LARI)}

In order to obtain information about previous trichinellosis outbreaks in Lebanon, general surveillance data were consulted on the official website of the Ministry of Public Health (MOPH). Furthermore, additional research was conducted on PubMed using the keywords "Lebanon" and "Trichinosis" or "Trichinellosis". There were no restrictions on article time period.

In order to obtain information about the current status of trichinellosis in Lebanon, we interviewed the head of the Animal Health Laboratory at the Lebanese Agricultural Research Institute (LARI) and five private hunters from different regions of the country. LARI is a governmental institute under the supervision of the Ministry of Agriculture, responsible for all animal-derived products on the market. A particular research station located in Fanar, Lebanon (Mount Lebanon) has recently been established for animal health and zoonosis control.

\section{Results}

\section{Case report in January 2019}

The index case was a hunter hospitalized in January 2019 for low grade fever, eyelid and facial edema, myalgia, and diarrhea, with diffuse pruriginous maculo-papular rash (patient 1). His blood tests revealed hypereosinophilia, elevated CPK and $\mathrm{LDH}$, and positive serology for trichinellosis. An investigation was then undertaken, upon which we discovered that fifteen people were present at a barbecue party and consumed hunted 
Table 1. Characteristics and symptoms described by patients.

\begin{tabular}{|c|c|c|c|c|c|c|c|c|c|c|}
\hline Patient & Age - Sex & $\begin{array}{c}\text { Fever onset } \\
\text { post barbecue }\end{array}$ & Edema & Myalgia & $\begin{array}{c}\text { Diarrhea } \\
\text { onset }\end{array}$ & $\begin{array}{c}\text { Skin } \\
\text { manifestations }\end{array}$ & $\begin{array}{c}\text { Eosinophilia } \\
\text { (cells/mL) }\end{array}$ & $\begin{array}{c}\text { Muscular } \\
\text { enzymes } \\
\text { level }\end{array}$ & $\begin{array}{c}\text { Trichinella } \\
\text { serology }\end{array}$ & $\begin{array}{c}\text { Case } \\
\text { category }\end{array}$ \\
\hline 1 & $32-\mathrm{M}$ & $38^{\circ} \mathrm{C}$ at day 5 & Eyelid and facial & Yes & 5 days & $\begin{array}{c}\text { Diffuse } \\
\text { maculo-papular } \\
\text { rash with pruritis }\end{array}$ & 8690 & $\begin{array}{l}\text { CPK } 331 \\
\text { LDH } 300\end{array}$ & $\begin{array}{l}\text { Positive (from } 11 \\
\text { to }>50 \mathrm{NTU} \text { ) }\end{array}$ & Confirmed \\
\hline 2 & $35-\mathrm{M}$ & $38.3^{\circ} \mathrm{C}$ at day 3 & Eyelid & Yes & 4 days & Urticaria & 7150 & $\begin{array}{l}\text { CPK } 420 \\
\text { LDH } 290\end{array}$ & $\begin{array}{c}\text { Positive (from } 4 \\
\text { to } 45 \mathrm{NTU} \text { ) }\end{array}$ & Confirmed \\
\hline 3 & $28-F$ & No & Facial & Yes & 7 days & Diffuse pruritis & 5500 & $\begin{array}{l}\text { CPK } 300 \\
\text { LDH } 280\end{array}$ & NA & Probable \\
\hline 4 & $29-\mathrm{M}$ & No & Eyelid and facial & Yes & 14 days & $\begin{array}{c}\text { Generalized } \\
\text { pruritis }\end{array}$ & 6000 & $\begin{array}{l}\text { CPK } 240 \\
\text { LDH } 273\end{array}$ & NA & Probable \\
\hline 5 & $30-\mathrm{F}$ & $39^{\circ} \mathrm{C}$ at day 7 & Eyelid & Yes & 3 days & $\begin{array}{l}\text { Lower limb } \\
\text { pruritis: maculo- } \\
\text { papular rash }\end{array}$ & 9070 & $\begin{array}{l}\text { CPK } 350 \\
\text { LDH } 160\end{array}$ & NA & Probable \\
\hline
\end{tabular}

boar meat grilled over a wood fire. His hunting partner (patient 2) was simultaneously hospitalized for urticaria and fever in a different ward at the same hospital. His physician was notified about the high suspicion for trichinellosis in patient 1 , and Trichinella serology testing confirmed the diagnosis. Three other probable cases were subsequently identified and treated as outpatients for similar but less intense symptoms (Table 1). They received symptomatic treatment for viral gastroenteritis. They were subjected to an oriented questionnaire and targeted blood tests were also performed that revealed hypereosinophilia and elevated CPK and LDH levels. The 10 remaining individuals were contacted for follow-up and serological testing, but refused to seek medical care since they were totally asymptomatic.

\section{Literature review and data collection in Lebanon}

\section{History of trichinellosis outbreaks in Lebanon from data of the MOPH}

In Lebanon, trichinellosis is a reportable disease to the MOPH. Surveillance data that go back to 2002 on the MOPH website were checked for positive trichinellosis cases. There were only three reported cases from 01/01/2002 to 27/05/2020: one case in January 2016 in Beirut and our two cases reported in January 2019 (our confirmed cases). The trichinellosis cases reported to the MOPH and the cases from the literature in Lebanon are summarized in Table 2.

\section{Data collection gathered from Lebanese wild boar hunters} and the Head of the Animal Health Laboratory, LARI

There are two subspecies of wild boar in Lebanon. The first, Sus scrofa libycus, also known as the Anatolian boar, is mainly found along the southern border of the country. The second, the Central European boar (Sus scrofa scrofa), was imported in the late 20th century. The initial population of this subspecies, originally imported for leisure and hunting by private individuals, later on mated and became established in the northern regions of Lebanon.

In Lebanon, the state does not currently regulate wild boar hunting. The most recent legislation regarding this issue dates from 05 April 2017, when a law (Law 580/04) was passed to require physical, mental, and reading (or oral) examinations before obtaining a hunting license.

Based on our interview with the Head of Animal Health laboratory, Trichinella larvae detection has been done on pork and wild boar meat cuts. However, no data are available from before 2006. Unlike pork cuts, which are received from the private and public sectors, wild boar meat is tested on demand by private hunters. The samples were mainly received from the Metn and Aaley regions. Paraspinal muscles undergo trichinoscopy and pepsin and $\mathrm{HCl}$ digestion [16] for larva detection. An average of four wild boar samples per year are tested at this institute, with no positive tests for Trichinella larvae since 2006.

There is no official hunting season in Lebanon. Even though the regulations are scarce, there is a consensus between hunters. First, female wild boars are only hunted starting November until September of the following year, in order to allow time for the piglets to mature and be independent of their mother. Male wild boars are hunted independently of the season. Second, three hunting techniques are agreed upon and used: long distance sniping with thermal scopes, and short distance hunting with shotguns by baiting them either with food or hunting dogs. Third, hunters must aim for critical body parts (brain, heart, lungs, or spine) knowing that any non-fatal or non-debilitating shot would enrage the boar, leading to possible physical harm to the hunters or damage to the environment.

\section{Discussion}

Although trichinellosis is a notifiable disease, the actual prevalence and incidence are unknown because the disease is difficult to identify due to a nonspecific picture or due to the absence of a pathognomonic clinical picture. Moreover, the disease could be self-limited without medical care seeking. Some outbreaks were not even published, such the one that occurred in East Beirut (Achrafieh) during the 1990-1991 war period. The estimated number of infected persons was around 200. At that time, the livestock was imported from Eastern Europe via Cyprus and the meat (beef, sheep, and pork) was delivered 
Table 2. Trichinellosis outbreaks in Lebanon.



by the same butcher. Trichinella larvae were suspected to have been transmitted from one livestock to another by crosscontamination. Cross-contamination occurred because the same knives, cutting boards, and other utensils were used by the butcher to cut meat of different pieces of infected pork and those of sheep and beef meat. In the food traditions of the Lebanese people, eating raw sheep meat is common. Consuming rare sheep or beef meat is also usual. During this outbreak, the group that consumed the meat of pork or wild boar ate it well cooked. Data collected for 40 patients at this time by the corresponding author, for oral presentation, during his internship in the university hospital located in the epidemic area of trichinellosis, revealed that patients eating raw sheep meat were mainly those who subsequently developed the disease, knowing that raw sheep meat should be consumed within 6-8 $\mathrm{h}$ after preparation and delivery by the butcher, for a matter of taste. Only seven patients ate pork meat, and three ate rare beef meat.

There is a general misconception among hunters and consumers that freezing the meat kills larval worms. Studies, however, have shown that not all species of Trichinella are sensitive to cold temperatures. In fact, $T$. spiralis larval worms are neutralized by freezing the pork either 20 days at $-15^{\circ} \mathrm{C}$ or 3 days at $-20{ }^{\circ} \mathrm{C}[10,12,29]$. In contrast, other species found in wild boars, such as $T$. britovi and T. nativa, are able to resist cold temperatures [10, 12, 21, 29]. To kill the encysted larvae, internal meat temperatures must reach $62{ }^{\circ} \mathrm{C}$ or more, taking into consideration the variability in heat distribution and cooking techniques [6]. Using wood fire cooking, such as in our case has shown that heat distribution might not be optimal in the core of the meat to kill encysted larvae. In our reported outbreak, the most likely cause was that the meat was not successfully grilled, hence, a part was served rare. As a result, wild boar cuts should be handled with precaution when using wood fire cooking.
Furthermore, international veterinary societies recommend that hunters should refrain from killing ill-looking boars, as well as avoid leaving behind animal remains and waste after discarding unwanted meat, to avoid the spread of Trichinella in the wildlife $[8,22]$. On the other hand, meat handlers (butchers and consumers) should follow certain hygiene rules (hand, utensil, and surface washing, with boiling water and diluted sodium hypochlorite solutions) [10, 12, 29].

As of 2020, Lebanon ranked as having the fourth highest inflation rate globally at $85.45 \%$. This rapid hyperinflation has severely affected the purchasing power of the Lebanese people, especially in impoverished communities. As a result, prices of imports, particularly food and livestock have inflated by more than $441 \%$ since 2019 . The most recent inflation rate stood at $144.1 \%$ during the month of October 2021. Meat prices have sky-rocketed and meat is no longer accessible to the lower- to average-income consumer. Consequently, other means of securing sufficient animal protein intake have been contemplated. One of these means is wild boar hunting for several reasons. First, pork meat consumption is not banned at the national level. Second, wild boars are abundant, as previously mentioned, and their hunting is unregulated. This creates a perfect recipe for gun-owning Lebanese who are looking for leisure or to provide food for their families.

In addition, the lack of veterinarian control increases the risk of unfortunate events. This is illustrated by the scarce amount of testing being done at the reference center for animal health control (LARI).

Our study was limited by the lack of further investigations to detect the species of Trichinella that was implicated in this case. It was not performed for financial reasons and futility regarding the management of the patients involved.

However, this is the first paper since the late 19th century that sheds light on trichinellosis outbreaks in Lebanon originating from wild boar meat consumption. 


\section{Conclusion}

Trichinellosis, a zoonosis typically unrecognized or undeclared, still represents a risk linked to the consumption of meat from wild animals, especially wild boar.

Given the looming risk of witnessing other trichinellosis outbreaks, the general population, and specifically veterinarians, hunters, and butchers, should be targeted by awareness campaigns regarding the disease and the risk of eating undercooked meat. They should also be instructed on how to properly prepare the meat in a risk-free manner. In addition, regulations should be implemented on this practice to avoid other outbreaks.

Acknowledgements. We thank the Lebanese Agricultural Research Institute and Lebanese hunters for their collaboration. No grants were received for this study. The authors report that they have no conflicts of interest.

\section{References}

1. Arévalo Velasco A, Bringas MJ, Rodríguez R, Menor A. 2009. Description of a trichinosis outbreak in the province of Salamanca. Revista Espanola De Quimioterapia, 22, 115-116.

2. Blondheim DS, Klein R, Ben-Dror G, Schick G. 1984. Trichinosis in southern Lebanon. Israel Journal of Medical Sciences, 20, 141-144.

3. Boutsini S, Papatsiros VG, Stougiou D, Marucci G, Liandris E, Athanasiou LV, Papadoudis A, Karagiozopoulos E, Bisias A, Pozio E. 2014. Emerging Trichinella britovi infections in free ranging pigs of Greece. Veterinary Parasitology, 199, 278-282.

4. Diaz JH, Warren RJ, Oster MJ. 2020. The disease ecology, epidemiology, clinical manifestations, and management of trichinellosis linked to consumption of wild animal Meat. Wilderness \& Environmental Medicine, 31, 235-244.

5. Djurković-Djaković O, Bobić B, Nikolić A, Klun I, DupouyCamet J. 2013. Pork as a source of human parasitic infection. Clinical Microbiology and Infection, 19, 586-594.

6. Food Safety and Inspection Service. 2018. FSIS compliance guideline for the prevention and control of Trichinella and other parasitic hazards in pork products, Guideline ID FSIS-GD2016-0002.

7. Gallardo MT, Mateos L, Artieda J, Wesslen L, Ruiz C, García MA, Galmés-Truyols A, Martin A, Hernández-Pezzi G, Andersson Y, Gárate T, Christensson D. 2007. Outbreak of trichinellosis in Spain and Sweden due to consumption of wild boar meat contaminated with Trichinella britovi. Euro Surveillance, 12, E070315.1.

8. Gottstein B, Pozio E, Nöckler K. 2009. Epidemiology, diagnosis, treatment, and control of trichinellosis. Clinical Microbiology Reviews, 22, 127-145.

9. Haim M, Efrat M, Wilson M, Schantz PM, Cohen D, Shemer J. 1997. An outbreak of Trichinella spiralis infection in southern Lebanon. Epidemiology and Infection, 119, 357-362.

10. Heaton D, Huang S, Shiau R, Casillas S, Straily A, Kong LK, $\mathrm{Ng} \mathrm{V}$, Petru V. 2018. Trichinellosis outbreak linked to consumption of privately raised raw boar meat - California, 2017. Morbidity and Mortality Weekly Report, 67, 247-249.

11. Kanán S, Saliba Y, Benoist G. 1980. Trichinosis in Lebanon. A survey on the 1978-1979 outbreak of trichinosis in Lebanon. Lebanese Medical Journal, 31, 339-348.

12. Larter NC, Forbes LB, Elkin BT, Allaire DG. 2011. Prevalence of Trichinella spp. in black bears, grizzly bears, and wolves in the Dehcho Region, Northwest Territories, Canada, including the first report of $T$. nativa in a grizzly bear from Canada. Journal of Wildlife Diseases, 47, 745-749.

13. Matossian RM, Ibrahim J. 1974. Rats, flies and mosquitos of Lebanon: pests, reservoirs and vectors of disease. Le Journal Médical Libanais. The Lebanese Medical Journal, 27, 375-381.

14. Matossian RM, Rebeiz J, Stephan E. 1974. Outbreak of trichinosis in Lebanon, 1970. A clinical and epidemiological study. Le Journal Médical Libanais. The Lebanese Medical Journal, 27, 267-273.

15. Matossian RM, Rebeiz J, Stephan E. 1975. Serodiagnosis by fluorescent antibody staining of an outbreak of trichinosis in Lebanon. Annals of Tropical Medicine and Parasitology, 69, 387-392.

16. Mayer-Scholl A, Pozio E, Gayda J, Thaben N, Bahn P, Nöckler K. 2017. Magnetic stirrer method for the detection of Trichinella larvae in muscle samples. Journal of Visualized Experiments: JoVE, 121, e55354.

17. Merab A, Melki L, Brounst G, Sioufi H. 1952. On a recent epidemic of trichinosis in North Lebanon. La Presse Médicale, 60, 1131-1132.

18. Millischer P, Dubarry J. 1942. Remarques à l'occasion d'une épidémie de trichinose sur la clinique, la thérapeutique et l'hygiène de cette affection. Biologie Médicale, 23, 23-48.

19. Murrell KD, Pozio E. 2011. Worldwide occurrence and impact of human trichinellosis, 1986-2009. Emerging Infectious Diseases, 17, 2194-2202.

20. Olaison L, Ljungström I. 1992. An outbreak of trichinosis in Lebanon. Transactions of the Royal Society of Tropical Medicine and Hygiene, 86, 658-660.

21. Pozio E, La Rosa G, Rossi P, Fico R. 1989. Survival of Trichinella muscle larvae in frozen wolf tissue in Italy. Journal of Parasitology, 75, 472-473.

22. Pozio E, Casulli A, Bologov VV, Marucci G, La Rosa G. 2001. Hunting practices increase the prevalence of Trichinella infection in wolves from European Russia. Journal of Parasitology, 87, 1498-1501.

23. Pozio E, La Rosa G, Gomez Morales MA. 2001. Epidemiology of human and animal trichinellosis in Italy since its discovery in 1887. Parasite, 8, S106-S108.

24. Rizk E, Berberian D. 1945. La trichinose au Liban. Revue Médicale Française du Moyen Orient, 4, 609.

25. Rostami A, Gamble HR, Dupouy-Camet J, Khazan H, Bruschi F. 2017. Meat sources of infection for outbreaks of human trichinellosis. Food Microbiology, 64, 65-71.

26. Sotiraki ST, Athanasiou LV, Himonas CA, Kontos VJ, Kyriopoulos I. 2001. Trichinellosis in Greece: a review. Parasite, 8, S83-S85.

27. Stephan E, Mamo A. 1952. New cases of trichinosis in Lebanon; grave neurologic involvement in one of the cases; value of muscular biopsy; treatment with ACTH. Le Journal Médical Libanais [The Lebanese Medical Journal], 5, 236-248.

28. Turiac IA, Cappelli MG, Olivieri R, Angelillis R, Martinelli D, Prato R, Fortunato F. 2017. Trichinellosis outbreak due to wild boar meat consumption in southern Italy. Parasites \& Vectors, $10,107$.

29. Wilson NO, Hall RL, Montgomery SP, Jones JL. 2002. Trichinellosis surveillance-United States, 2008-2012. Morbidity and Mortality Weekly Report. Washington, D.C: Surveillance Summaries, Vol. 64. p. 1-8.

30. World Bank. 2021. Lebanon economic monitor, in Spring 2021. Washington, DC: World Bank.

31. Wortabet J. 1881. An outbreak of trichinosis (?) from eating the flesh of a wild boar. Lancet, 117, 454-455. 
Cite this article as: Khalil G, Marty P, Hage K, Sfeir S, El Hage J, Bou Assi T, Rassam M, Pomares C \& Mikhael E. 2022. Could the re-emerging practice of wild boar hunting linked to the recent economic crisis lead to new outbreaks of trichinellosis in Lebanon?. Parasite 29, 11 .

\section{PARASTE}

An international open-access, peer-reviewed, online journal publishing high quality papers on all aspects of human and animal parasitology

Reviews, articles and short notes may be submitted. Fields include, but are not limited to: general, medical and veterinary parasitology; morphology, including ultrastructure; parasite systematics, including entomology, acarology, helminthology and protistology, and molecular analyses; molecular biology and biochemistry; immunology of parasitic diseases; host-parasite relationships; ecology and life history of parasites; epidemiology; therapeutics; new diagnostic tools.

All papers in Parasite are published in English. Manuscripts should have a broad interest and must not have been published or submitted elsewhere. No limit is imposed on the length of manuscripts.

Parasite (open-access) continues Parasite (print and online editions, 1994-2012) and Annales de Parasitologie Humaine et Comparée (1923-1993) and is the official journal of the Société Française de Parasitologie. 